\title{
Slag Cleaning Equilibria in Iron Silicate Slag-Copper Systems
}

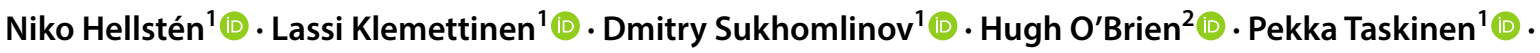 \\ Ari Jokilaakso ${ }^{1} \mathbb{0}$. Justin Salminen ${ }^{3}$
}

Received: 5 February 2019 / Revised: 12 July 2019 / Accepted: 15 July 2019 / Published online: 31 July 2019

(c) The Author(s) 2019

\begin{abstract}
In this study, the equilibrium distributions of selected trace elements between molten iron-saturated copper alloy and selected iron silicate slags were measured, and the effects of silica fluxing on them. In addition to the copper and iron main components of the system, trace elements like antimony, gallium, germanium, gold, indium, and silver were added in experiments that spanned the temperature range of 1473-1573 K (1200-1300 $\left.{ }^{\circ} \mathrm{C}\right)$. Experimental charges were quenched and prepared in polished mounts. In situ analyses of the resulting phases were made directly on the mounts without the need of phase separation prior to analysis. Electron probe X-ray microanalysis was used for concentrations at or above approximately 100 ppmw, and laser ablation-inductively coupled plasma-mass spectrometry for the lower concentrations in the slags. The very low slag concentrations of germanium, antimony, and indium obtained indicate that these elements can be removed from the slag by reduction, whereas gallium concentrations in the slag were high. Consequently, gallium removal from iron residues, such as zinc smelting jarosite, is difficult without volatilization. Based on the present observations, the industrial reduction processes for the treatment of smelting and refining slags as well as for the processing of iron residues, and extracting the reducible metal oxides and their metal values can be optimized. The target in fluxing should be to maintain the slag compositions with a silica concentration higher than about $28 \mathrm{wt} \%$.
\end{abstract}

Keywords Fayalite slag $\cdot$ Jarosite $\cdot$ Slag cleaning $\cdot$ Antimony $\cdot$ Gallium $\cdot$ Germanium $\cdot$ Gold $\cdot$ Indium $\cdot$ Silver

\section{Introduction}

Slags produced from the smelting and refining process contain significant quantities of metals that need to be recovered in a separate slag cleaning step [1]. In copper smelting, slag cleaning is performed by either of two major technologies: slag milling and flotation [2], or reduction followed by settling in an electric furnace [3]. In contrast, slags produced in the nickel [4], lead [5], and tin [6] industries typically are cleaned in an electric furnace process using coke reduction.

The contributing editor for this article was Markus Reuter.

Pekka Taskinen

pekka.taskinen@aalto.fi

1 Department of Chemical and Metallurgical Engineering, School of Chemical Engineering, Aalto University, P.O. Box 16100, 00076 Aalto, Finland

2 Geological Survey of Finland (GTK), Vuorimiehentie 5, 02150 Espoo, Finland

3 Boliden Kokkola, Sinkkiaukio 1, 67900 Kokkola, Finland
The increasing awareness to properly handle harmful industrial wastes [7] has also increased our attention to various hydrometallurgical iron residues produced in extraction technologies, particularly jarosite produced in zinc smelting [8-14]. The metals contained in these residues (e.g., Zn, $\mathrm{Pb}$, and $\mathrm{Cu}$ ) are recovered either from the flue dust or in metal or speiss forming during the reductive treatment of the iron slag.

Fundamental trace element distribution and solubility data concerning the reduction process of iron silicate slags, particularly at iron saturation, are scarce. The limiting phase boundary in the reduction process is the iron saturation surface where the only variable in isothermal conditions is the composition of the slag. In the simplest case of the $\mathrm{Fe}-\mathrm{O}-\mathrm{SiO}_{2}$ slags, this means its $\mathrm{Fe}: \mathrm{SiO}_{2}$ ratio, and in case the slag is modified to enhance metal recoveries, then typically also its $\mathrm{CaO}: \mathrm{SiO}_{2}$ and $\mathrm{MgO}: \mathrm{SiO}_{2}$ ratios will be of interest. Previous relevant research includes Kim et al. [15] who studied modifiers and minor element behaviors between copper and iron silicate slags. Zhai et al. [16] as well as Banda et al. [17] studied the effects of $\mathrm{CaO}$ modification 
on cobalt recovery from slag. Surapunt et al. [18] measured zinc distributions between copper- and iron-saturated silicate slags in open and closed systems. Zajaczkowski et al. [19] studied the distribution of lead and copper in aluminasaturated flash smelting slag. Limited data are available also for $\mathrm{MgO}$-saturated nickel smelting slags [20-22].

The aim of this study was to measure the equilibrium distributions of selected trace components over the temperature range $1473-1573 \mathrm{~K}\left(1200-1300{ }^{\circ} \mathrm{C}\right)$ between molten ironsaturated copper alloy and selected iron silicate slags, and to demonstrate the effects on these distributions at different silica flux concentrations (effectively by varying the $\mathrm{Fe}: \mathrm{SiO}_{2}$ ratio). This is a fundamental study of reduction smelting of jarosite and other iron residues.

\section{Experimental}

The base slag-metal system used in this study, $\mathrm{Cu}-\mathrm{Fe}-\mathrm{O}_{2}-\mathrm{SiO}_{2}$, has four components (denoted as $\mathrm{C}$ ) in its simplest form, which is increased by one when a trace element is added. Therefore, in the experimental setups, where three phases (denoted as $f$ ) are in equilibrium under isothermal and isobaric conditions, the degree of freedom or the number of free variable $F$ is as follows:

$F=C-f+2=1$.

The free variable will be set by the $\mathrm{Fe}: \mathrm{SiO}_{2}$ ratio of the slag which will be fixed in each $\mathrm{P}, \mathrm{T}$ point. The base system without trace elements is thus self-equilibrating and reaches equilibrium without control of the internal atmosphere composition. Consequently, an inert gas was used as the furnace atmosphere. The addition of each trace element adds one degree of freedom to the equilibrium system. The equilibrium was measured experimentally in this study as trace element concentrations of iron-saturated copper alloy and the slag.

The experiments were conducted at temperatures of $1473 \mathrm{~K}\left(1200{ }^{\circ} \mathrm{C}\right), 1523 \mathrm{~K}\left(1250{ }^{\circ} \mathrm{C}\right)$, and $1573 \mathrm{~K}\left(1300{ }^{\circ} \mathrm{C}\right)$ using four different $\mathrm{Fe}: \mathrm{SiO}_{2}$ ratios $\left(\mathrm{Fe}: \mathrm{SiO}_{2}=3.1,2.3,1.8\right.$, and $1.5(\mathrm{w} / \mathrm{w}))$. Each experiment was repeated at each temperature at 1 atm total pressure, giving a total of 29 experiments, including the time series of five annealings for $1 \mathrm{~h}$, $2 \mathrm{~h}, 3 \mathrm{~h}, 4 \mathrm{~h}$, and $5 \mathrm{~h}$ for determining the necessary equilibration time.

Prior to the experiments, $\mathrm{Fe}_{2} \mathrm{O}_{3}$ was reduced by heating $10 \mathrm{~g}$ of $\mathrm{Fe}_{2} \mathrm{O}_{3}$ in a quartz crucible in a vertical tube furnace at $800{ }^{\circ} \mathrm{C}$ for $14.5 \mathrm{~h}$ in controlled $\mathrm{PO}_{2}$, obtained using $\mathrm{CO}$ (purity $\geq 99.97$ vol\%; Aga-Linde, Finland) and $\mathrm{CO}_{2}$ (purity $\geq 99.9993$ vol\%; Aga-Linde, Finland) gases with a volumetric ratio of 50:50 (flow rates for both gases were $100 \mathrm{~mL} / \mathrm{min}$ (STP) during the experiments). The resulting material was analyzed by XRD using XPertPro software
(Panalytical, The Netherlands) showing only peaks for $\mathrm{FeO}$. Visually, the reddish color of $\mathrm{Fe}_{2} \mathrm{O}_{3}$ had changed to black after the reduction. The reduction of $\mathrm{Fe}_{2} \mathrm{O}_{3}$ decreases the evolution of oxygen during the initial periods of the equilibration experiments and shortens the equilibration time.

An iron crucible (length $\approx 15 \mathrm{~mm}$, outer diameter of $5.8 \mathrm{~mm}$ or less) was prepared from $6 \mathrm{~mm}$ pure Fe rod, see Table 1, by cutting and drilling into a crucible shape. The iron-saturated iron-silicate based slag mixture was prepared by mixing prereduced $\mathrm{FeO}$ and $\mathrm{SiO}_{2}$ powders to form a slag, which initially contained $20,25,30$, and $35 \mathrm{wt} \% \mathrm{SiO}_{2}$. In

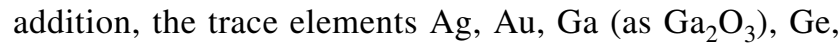
$\mathrm{In}$, and $\mathrm{Sb}$ were simultaneously added as powders into the copper-slag mixtures, each assaying $1 \mathrm{wt} \%$ of the mass of copper. The slag-alloy mixture containing the trace elements and slag weighed $0.2 \mathrm{~g}$ each, and thus in the iron crucible, their corresponding weight ratio was initially 1:1.

The semisealed ampoule was formed from a quartz tube ( $8 \mathrm{~mm}$ OD, $6 \mathrm{~mm}$ ID; Heraeus: grade HSQ 300) by a hydrogen-oxygen torch. A $1.9 \mathrm{~mm}$ diameter hole was drilled into the ampoule $40 \mathrm{~mm}$ above the bottom of the tube using a dentist's drill. The iron crucible containing the sample was inserted into the tube. Subsequently, the quartz tube was cut to a length of $50-80 \mathrm{~mm}$, and a hook for suspension was formed on the top-end using a hydrogen-oxygen flame. This operation left the drilled hole as the only opening into the ampoule to the surrounding furnace atmosphere.

In this method, we assumed that the semiclosed ampoule forms a kinetic barrier for the volatile elements but allows equilibration with, e.g., the gaseous $\mathrm{CO}-\mathrm{CO}_{2}$ mixtures if needed. Figure 1a shows a schematic of the semisealed ampoule arrangement containing the iron crucible with the sample in it. During equilibration, the gas phase above the liquid slag within the ampoule saturates with the volatile elements. The small hole decreases the removal rate of the saturated gas phase, by Knudsen-like gas diffusion through the hole, while the saturated gas phase reduces transfer of the volatile elements from the condensed phases into the gas

Table 1 The used raw materials, their suppliers, and purities

\begin{tabular}{lll}
\hline Substance & Supplier & Purity (wt\%) \\
\hline $\mathrm{Ag}$ & Alfa-Aesar, Germany & 99.95 \\
$\mathrm{Au}$ & Alfa-Aesar, Germany & 99.96 \\
$\mathrm{Cu}$ & Boliden Harjavalta, Finland & 99.99 \\
$\mathrm{Fe}($ rod) & Goodfellow, UK & $99.99+$ \\
$\mathrm{Fe}_{2} \mathrm{O}_{3}$ & Alfa-Aesar, Germany & 99.999 \\
$\mathrm{Ga}_{2} \mathrm{O}_{3}$ & Alfa-Aesar, Germany & 99.99 \\
$\mathrm{Ge}_{\mathrm{In}}$ & Alfa-Aesar, Germany & 99.999 \\
$\mathrm{Sb}$ & Alfa-Aesar, Germany & 99.99 \\
$\mathrm{SiO}$ & Alfa-Aesar, Germany & 99.999 \\
\hline
\end{tabular}


Fig. 1 a A schematic of the cross section of the semiclosed silica ampoule, iron crucible. and the slag- $(\mathrm{CuFe})$ alloy sample. b Schematic of the semiclosed gas phase ( $p$ is partial pressure of a species) arrangement and the expected behavior of volatiles in the experimental technique used

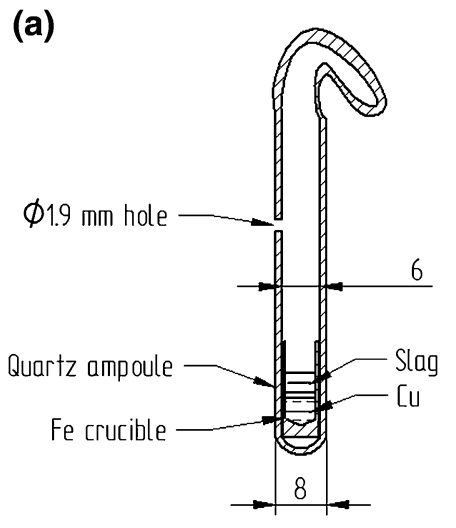

(b)

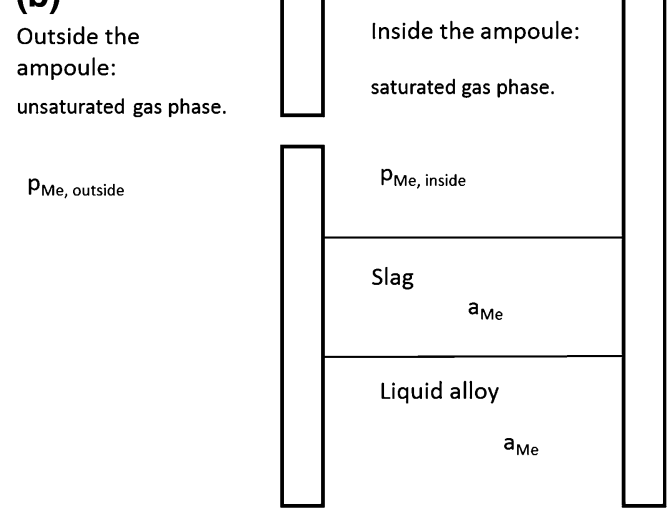

flow. Thus, it was expected that the volatile elements equilibrate between slag and alloy without concentration gradients, and remain in the sample during annealing and after quenching in sufficient concentrations for in situ analysis with EPMA or LA-ICP-MS. In equilibrium, the distribution coefficients of the metals between the copper alloy, slag and metallic Fe, remains the same regardless of slow evaporation of the metals, provided the diffusional mass transfer in the slag and alloy are faster than the volatilization. Figure $1 b$ illustrates basics of the new concept.

When $p_{\mathrm{Me}, \mathrm{s}}, p_{\mathrm{M}, \mathrm{M}}<p_{\mathrm{Me}, \text { inside }}$, mass transfer and volatilization of the metal/oxide to the surrounding furnace atmosphere will occur, but it is assumed to be slow compared to vaporization processes on the slag surface. When $p_{\text {Me,inside }}<p_{\text {Me,outside }}$, the metal/oxide-containing gas moves outside the ampoule through the hole. In this experimental arrangement, the molten alloy-solid alloy equilibrium with $\mathrm{FeO}$ in the slag forms the prevailing oxygen pressure in the ampoule.

The equilibration experiments were conducted in a vertical tube furnace under $\mathrm{N}_{2}$ (purity $\geq 99.999$ vol\%; Aga-Linde, Finland) atmosphere using a similar setup and method as described earlier [23]. The semisealed ampoule containing the sample was introduced into the furnace work tube from its lower end and suspended there with a $0.5 \mathrm{~mm}$ Pt-wire. The ampoule was held in the low end, while the furnace was sealed, and the gas atmosphere flushed with flowing nitrogen for $30 \mathrm{~min}$, at a flow rate of $200 \mathrm{~mL} / \mathrm{min}$. After flushing, the ampoule was raised to the hot zone of the furnace, equilibrated and quenched into a $273.15 \mathrm{~K}\left(0^{\circ} \mathrm{C}\right)$ ice-water mixture. During the experiments, temperature of the sample was monitored using a calibrated, S-type (Pt/Pt90 + Rh10; $\pm 2{ }^{\circ} \mathrm{C}$ ) thermocouple (Johnson-Matthey, UK).

Time required for equilibration was determined experimentally as $2 \mathrm{~h}$ based on changes in the slag composition. After quenching, the sample was dried, mounted into epoxy, cut, and polished using conventional wet metallographic methods. The sample surface was made conductive with carbon coating by evaporation.
Microstructure observations and preliminary analysis of chemical compositions of the phases were obtained using a Tescan MIRA 3 Scanning Electron Microscope (Tescan, Czech Republic) equipped with an UltraDry silicon drift energy dispersive spectrometer and a NSS microanalysis software (Thermo Fischer Scientific, USA). The accurate chemical phase compositional analyses were carried out by EPMA using a Cameca SX100 (Cameca SAS, France). The EPMA was operated using $20 \mathrm{kV}$ accelerating voltage, 40 nA beam current, and 50-100 $\mu \mathrm{m}$ defocused electron beam. The external standard materials and analyzed lines used in the EPMA were: $\mathrm{O} \mathrm{K}_{\alpha}$ (hematite), $\mathrm{Si} \mathrm{K}_{\alpha}$ (quartz), $\mathrm{Fe} \mathrm{K}_{\alpha}$ (hematite), $\mathrm{Cu} \mathrm{K} \mathrm{K}_{\alpha}(\mathrm{Cu}), \mathrm{Ag} \mathrm{L}_{\alpha}(\mathrm{Ag}), \mathrm{Sb} \mathrm{L}_{\alpha}(\mathrm{SbTe}), \mathrm{Au} \mathrm{L} \mathrm{L}_{\alpha}$ ( $\mathrm{Au}), \mathrm{Ga} \mathrm{K}_{\alpha}(\mathrm{GaAs}), \mathrm{Ge} \mathrm{K}_{\alpha}(\mathrm{Ge})$, and In $\mathrm{L}_{\alpha}$ (InAs). The analytical results of the primary EPMA WDS data were corrected using a PAP-based online matrix correction software [24] by Cameca.

The concentrations of all trace elements, apart from gallium, in the slag were below the detection limits of EPMA. Therefore, the slag phase was also analyzed with LA-ICPMS technique. A Photon Machines Analyte Excite 193 nm 4 ns ArF laser ablation device (Teledyne CETAC Technologies, USA), coupled with a Nu AttoM single-collector ICPMS (Nu Instruments Ltd., UK), housed at Geological Survey of Finland, was utilized. The laser energy was set to $30 \%$ of $5.0 \mathrm{~mJ}$, resulting in a fluence of $2.5 \mathrm{~J} / \mathrm{cm}^{2}$ on the sample surface. A spot size of $85 \mu \mathrm{m}$ and operating frequency of $10 \mathrm{~Hz}$ were selected. The estimated detection limits by the equipment are collected in Table 2.

The mass spectrometer was operated in FastScan mode in low resolution $(\Delta M / M=300)$ for higher sensitivity. An analysis protocol of 5 preablation pulses for removal of the carbon coating and possible contaminants from the surface, 20-s pause, 25-s gas background analysis, and 400 ablation pulses was adopted. At least six points were analyzed from the slag phase of each sample, and the averages and their standard deviations were used in the following chapters.

NIST 612 SRM [25] was used as the external standard and ${ }^{29} \mathrm{Si}$ as the internal standard for analyses. NIST 610 
Table 2 The estimated detection limits of EPMA and LA-ICP-MS (ppmw)

\begin{tabular}{|c|c|c|c|c|c|c|c|c|c|}
\hline $\mathrm{O}$ & $\mathrm{Si}$ & $\mathrm{Fe}$ & $\mathrm{Cu}$ & $\mathrm{Ag}$ & $\mathrm{Sb}$ & $\mathrm{Au}$ & $\mathrm{Ga}$ & $\mathrm{Ge}$ & In \\
\hline \multicolumn{10}{|c|}{ Detection limit: EPMA (Cu-Fe-alloy and Fe-alloy) } \\
\hline 1130 & 130 & 230 & 170 & 460 & 170 & 870 & 260 & 320 & 180 \\
\hline \multicolumn{10}{|c|}{ Detection limit: EPMA (slag) } \\
\hline 1250 & 100 & 270 & 140 & 400 & 150 & 750 & 220 & 270 & 160 \\
\hline \multicolumn{10}{|c|}{ Detection limit: LA-ICP-MS (slag) } \\
\hline & ${ }^{29} \mathrm{Si}:$ & & & $\begin{array}{l}{ }^{107} \mathrm{Ag}: 0.005 \\
{ }^{109} \mathrm{Ag}: 0.004\end{array}$ & $\begin{array}{l}{ }^{121} \mathrm{Sb}: 0.009 \\
{ }^{123} \mathrm{Sb}: 0.010\end{array}$ & ${ }^{197} \mathrm{Au}: 0.001$ & ${ }^{69} \mathrm{Ga}: 0.006$ & $\begin{array}{l}{ }^{72} \mathrm{Ge}: 0.030 \\
{ }^{73} \mathrm{Ge}: 0.040\end{array}$ & ${ }^{115} \mathrm{In}: 0.002$ \\
\hline
\end{tabular}

SRM, USGS BHVO-2G, and BCR-2G reference glasses were analyzed as unknowns for monitoring data quality. The data collected from the mass spectrometer were analyzed using GLITTER software [26]. The trace element concentrations obtained by LA-ICP-MS and presented in this article have been calculated using the isotopes: ${ }^{72,73} \mathrm{Ge},{ }^{107,109} \mathrm{Ag},{ }^{115} \mathrm{In},{ }^{121,123} \mathrm{Sb}$, and ${ }^{197} \mathrm{Au}$.

\section{Results and Discussion}

A typical microstructure of a quenched sample is shown in Fig. 2. The liquid $\mathrm{Cu}$ and slag are clearly visible and present in large areas. Microstructures in slow quenched areas of the samples show minor precipitation, more pronounced than in experiments where small, open crucibles were used [27]. Very small $\mathrm{Fe}_{3} \mathrm{O}_{4}$ precipitates were common in the slag, and the copper alloy in thick parts of the specimen indicated severe segregation. The wellquenched areas, showing microcrystalline or glassy structure in the SEM micrographs, were selected for the EPMA and LA-ICP-MS measurements.

\section{Solubilities of the Base Metals}

The final concentration of copper in reducing conditions of the slag cleaning at copper saturation is not at all well known in the literature. That endpoint is on the iron saturation boundary in the $\mathrm{Fe}-\mathrm{O}-\mathrm{SiO}_{2}$ system. Therefore, the copper concentration of the iron silicate slag was measured as a function of silica concentration of the slag at 1473 (1200) to $1573 \mathrm{~K}\left(1300^{\circ} \mathrm{C}\right)$, in saturation with solid iron. The results are shown in Fig. 3 as a function of measured silica concentration of the slag, calculated from the EPMA data. A comparison of the present observations with Surapunt et al. [18] shows excellent agreement at $1200-1250{ }^{\circ} \mathrm{C}$.

The solubility of iron in liquid copper in these experiments was constantly controlled in the presence of the solid iron crucible that held the experimental charges. Therefore, the composition of the slag or its iron oxide activity does not affect the solubility of iron in the molten copper-based alloy. The present results with the individual standard uncertainty of each point $(1 \times \sigma)$ are shown in Fig. 4 .

Solubility of iron in liquid copper was also measured in this slag-copper alloy-solid iron equilibrium system, which contained 2.6-2.9 wt\% other alloying elements in the metallic copper phase. The average values obtained were 4.0, 5.5 and $7.4 \mathrm{wt} \%[\mathrm{Fe}]_{\mathrm{Cu}}$ at temperatures $1473 \mathrm{~K}\left(1200{ }^{\circ} \mathrm{C}\right)$,
Fig. 2 Microstructures of slagmetal-iron crucible interfaces after equilibration and quenching from $1473(1200)$ and $1573 \mathrm{~K}\left(1300{ }^{\circ} \mathrm{C}\right)($ white-Cu alloy, light gray-Fe(s) and dark gray-slag)
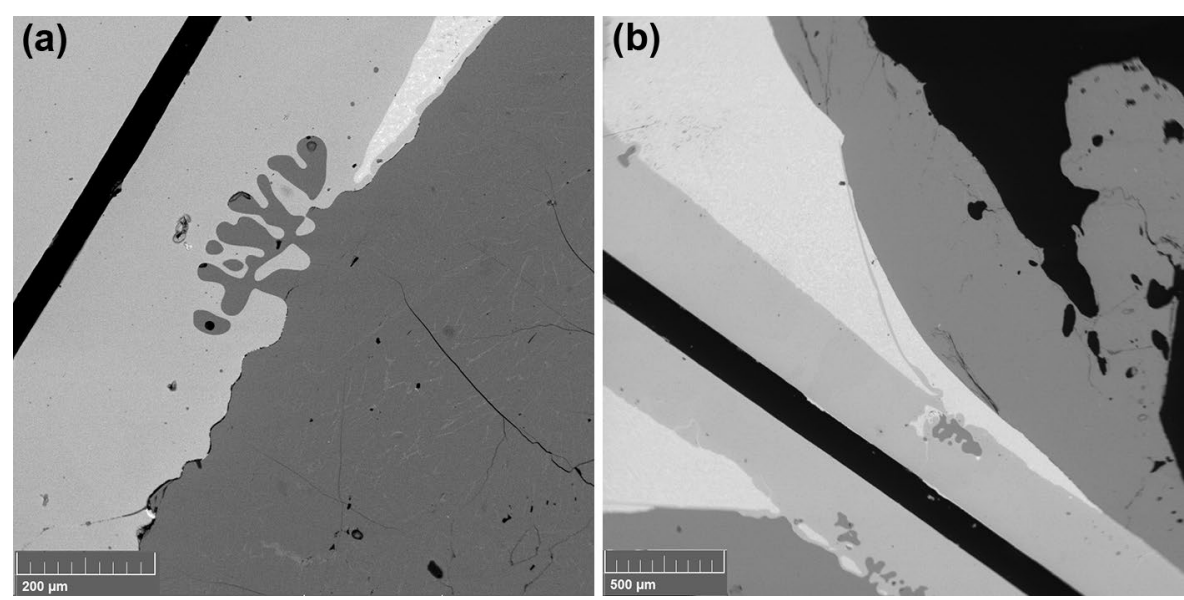


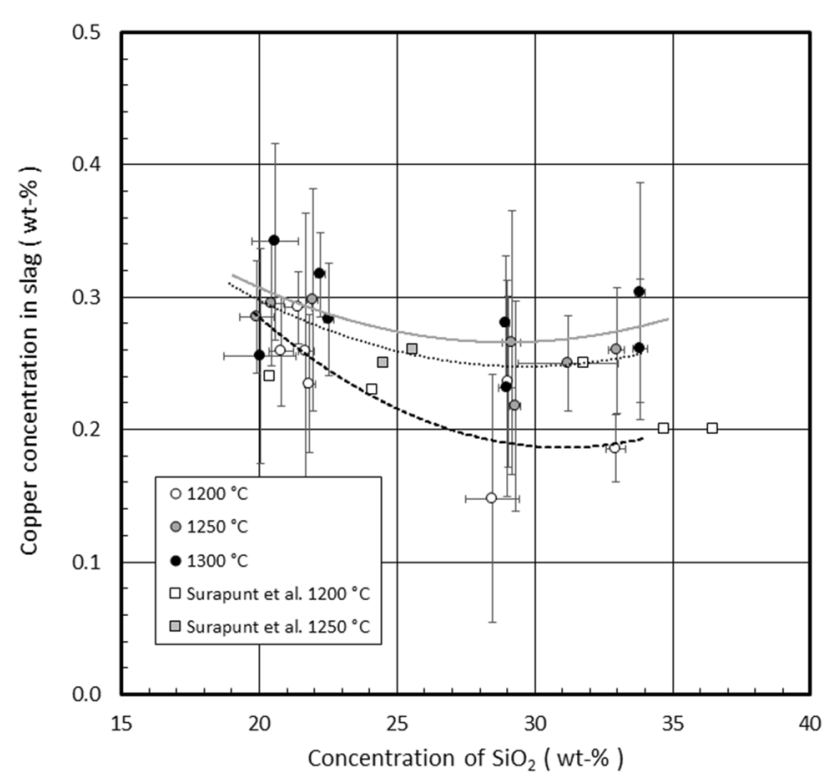

Fig. 3 Copper solubility in $\mathrm{Fe}-\mathrm{O}-\mathrm{SiO}_{2}$ slags at iron and copper saturations at $1473-1573 \mathrm{~K}\left(1200-1300{ }^{\circ} \mathrm{C}\right)$; data by Surapunt et al. from [18]

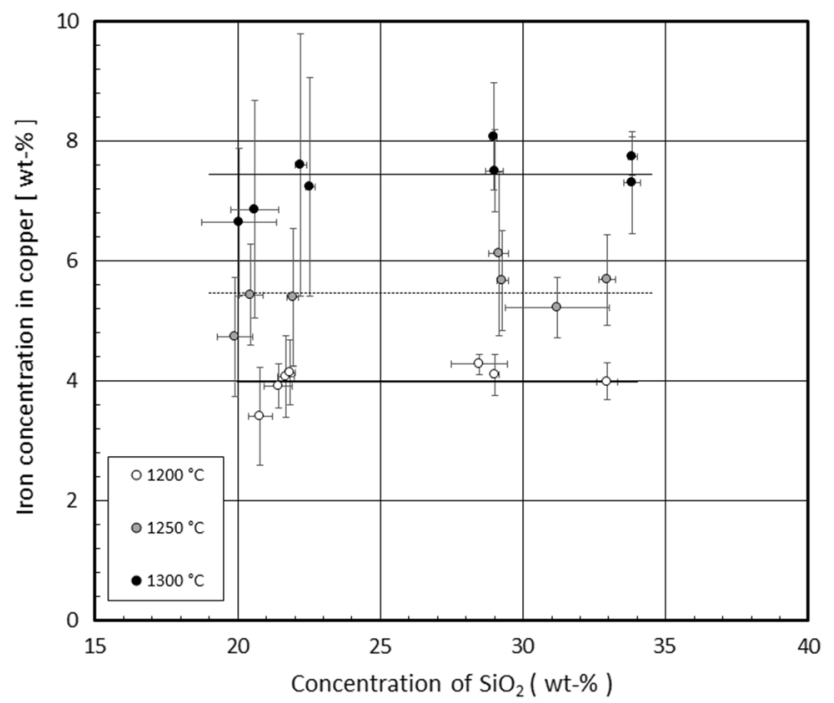

Fig. 4 Solubility of iron in molten copper at iron saturation in the present experiments at $1473-1573 \mathrm{~K}\left(1200-1300^{\circ} \mathrm{C}\right)$

$1523 \mathrm{~K}\left(1250{ }^{\circ} \mathrm{C}\right)$ and $1573 \mathrm{~K}\left(1300{ }^{\circ} \mathrm{C}\right)$, respectively. The values are in good agreement with the experimental data from the pure binary $\mathrm{Cu}-\mathrm{Fe}$ system by Oelsen et al. [28], which has been evaluated as the most reliable experimental dataset by several critical assessments [29-31]. It is evident that in addition to silver and gold [32, 33], also other alloying elements of copper increase the activity coefficient of iron in copper alloys, which explains the approximately 0.5 wt\% lower iron solubilities measured in the present case, compared to the data of Oelsen et al. [28] from pure binary copper-iron alloys.

\section{Solubilities of the Trace Elements in the Slag}

The equilibrium concentrations of trace elements in the slag at copper and iron saturation predict the lowest concentrations achievable in the reduction process of slag cleaning with copper alloy as the collector metal. Thus, they can be regarded as the limiting minimum values in the industrial operations as well, see, e.g., Hughes [34]. Additionally the selected slag-to-metal ratio determines the maximum recoveries in the collector metal, in the absence of volatilization [35].

The trace element solubilities in the slags from $\mathrm{Cu}+1$ $\mathrm{wt} \% \mathrm{Me}$ copper alloy obtained in this study indicate a general decreasing trend when silica concentration is increased. This means that the losses of valuable metals increase when the slag used in the smelting is more iron oxide rich than the orthosilicate composition of the $\mathrm{Fe}-\mathrm{O}-\mathrm{SiO}_{2}$ system or have a Fe: $\mathrm{SiO}_{2}>1.86$ (w/w) or $29.5 \mathrm{wt} \% \mathrm{SiO}_{2}$.

The solubilities of silver and gold in the slag as a function of silica concentration at various temperatures are shown in Figs. 5 and 6. The experimental uncertainties of silver concentrations were high in some samples, but no obvious reason was found in their micrographs. The silver concentration obtained at iron saturation is relatively high compared to the other precious and platinum group metals [36], between 5 and $20 \mathrm{ppm}$. Gold dissolved in iron silicate slags much less, and its concentration was always below $0.3 \mathrm{ppm}$. Slight tendencies toward lower solubilities at low temperatures can be recognized in the present experimental observations. The

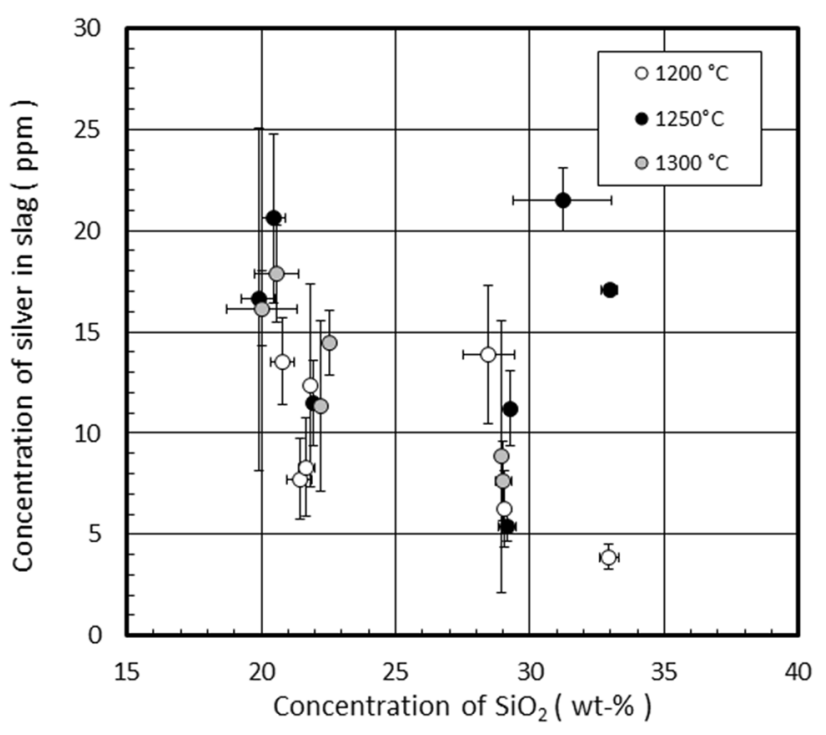

Fig. 5 Concentrations of silver in iron silicate slag at copper and iron saturations at $1473-1573 \mathrm{~K}\left(1200-1300{ }^{\circ} \mathrm{C}\right)$ 


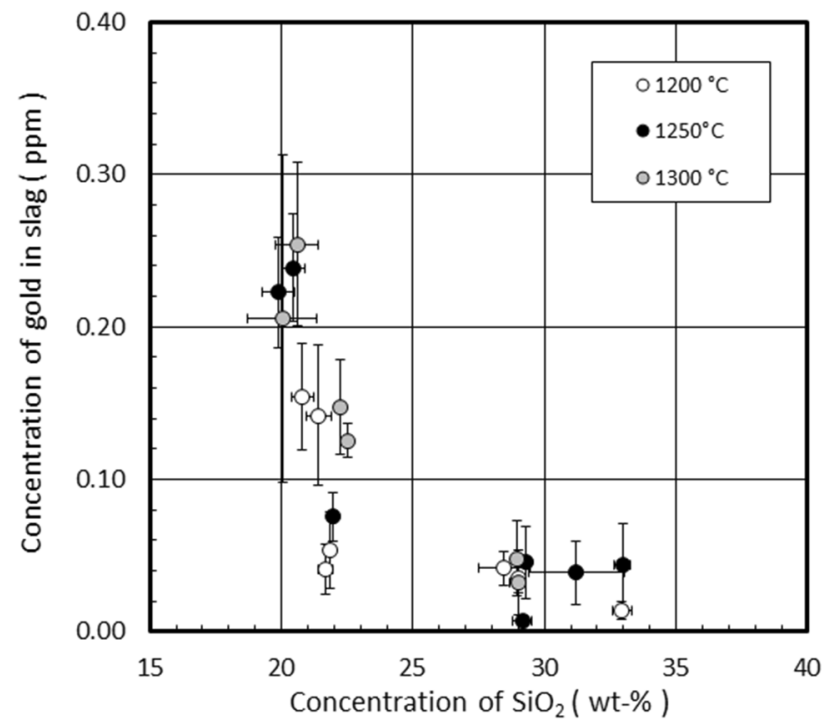

Fig. 6 Concentration of gold in iron silicate slags under copper- and iron saturation conditions at $1473-1573 \mathrm{~K}\left(1200-1300{ }^{\circ} \mathrm{C}\right)$

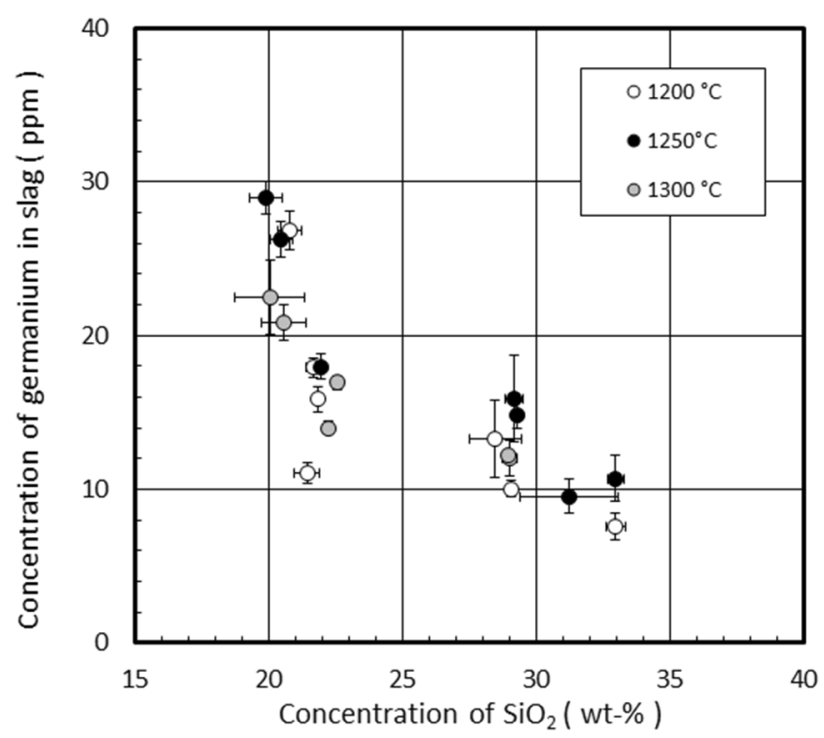

Fig. 7 Concentration of germanium in iron silicate slag at copper and iron saturation

obtained gold concentration is much lower than earlier data on metallurgical slags [37] if recalculated to the solubility values of pure gold.

The concentrations of germanium and indium in the slag at iron saturation were in the ranges of $10-30 \mathrm{ppm}$ and $60-70 \mathrm{ppm}$, respectively. The experimental data at $1200-1300{ }^{\circ} \mathrm{C}$ are shown in Figs. 7 and 8 and plotted as a function of the measured silica concentrations of the iron silicate slag. A sample at $1200{ }^{\circ} \mathrm{C}$ had higher uncertainties than the other experiments, but no indication of the source of high scatter could be identified from its microstructure.

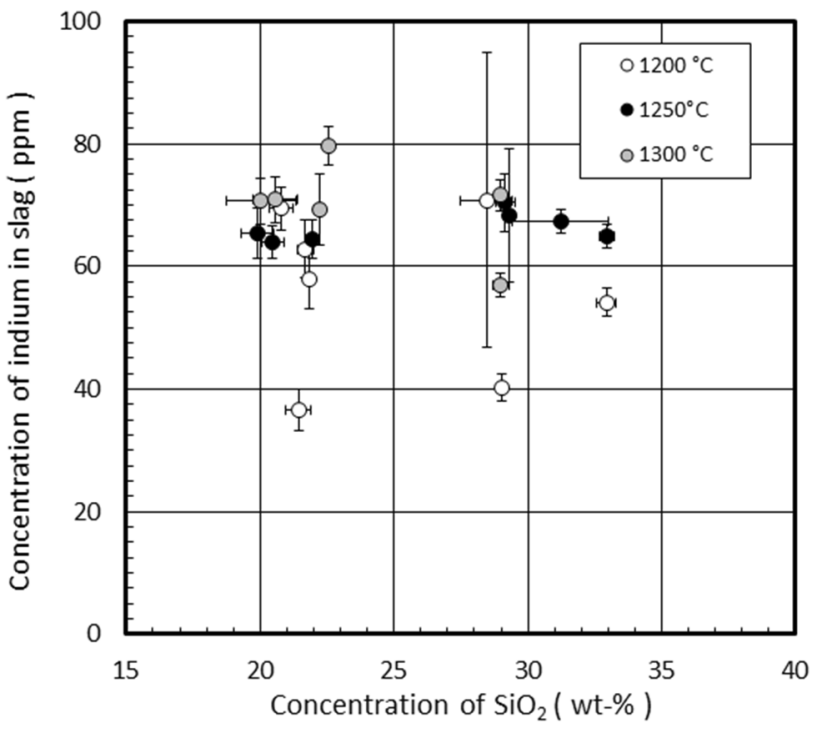

Fig. 8 Concentration of indium in iron silicate slag at copper and iron saturation

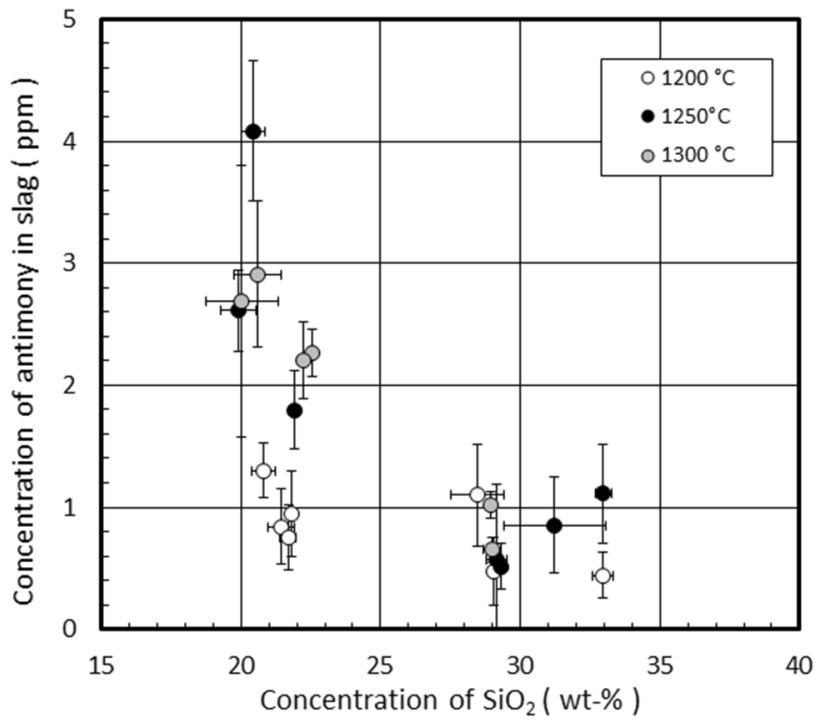

Fig. 9 Concentration of antimony in iron silicate slag at copper and iron saturation

A solubility study at $1500{ }^{\circ} \mathrm{C}$ and carbon- $\mathrm{CO}(\mathrm{g})$ saturation in iron-free alumina-lime silicate melts [38] suggests much smaller indium concentrations, but its oxygen partial pressure was much lower, $\log _{10} \mathrm{PO}_{2} / \mathrm{atm}=-16$ to -17 , than that in the present study (Figs. 7, 8).

The concentration of antimony in slag at iron saturation obtained in this study was around 1-4 ppm (Fig. 9). Copper was not effective collector for gallium, and its concentration in the slag remained at as high as around $2000 \mathrm{ppm}$ or 0.2 wt\% (Fig. 10). The obtained concentration of antimony is much lower than reported by Goto et al. [39] at 1200 and 


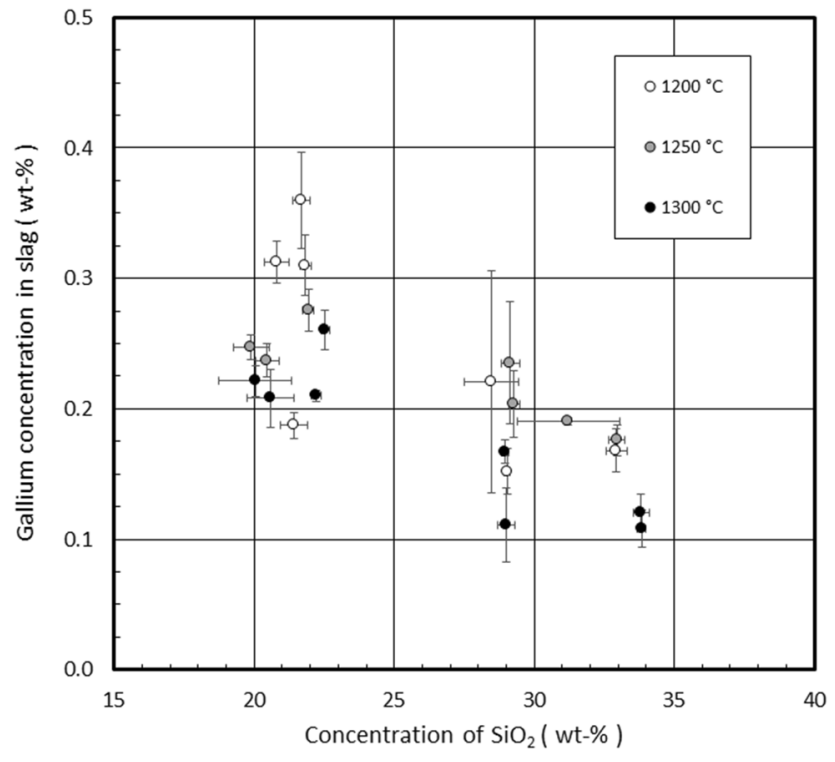

Fig. 10 Concentrations of gallium in iron silicate slags at copper and iron saturations; EPMA data

$1250{ }^{\circ} \mathrm{C}$ in silica-saturated iron silicate slags, close to iron saturation of about $6 \mathrm{wt} \% \mathrm{Fe}_{3} \mathrm{O}_{4}$ in the slag.

\section{Distribution Coefficients for the Trace Elements}

The distribution coefficient of an element $\mathrm{Me}$ in metal alloy-slag systems is defined in the current study as

$L^{\mathrm{m} / \mathrm{s}}(\mathrm{Me})=\frac{[\mathrm{wt} \% \mathrm{Me}]}{(\mathrm{wt} \% \mathrm{Me})}$,

where [] refers to the metal alloy (m) and () to the iron silicate slag (s) melt. Its relationships with the thermodynamic properties of element $\mathrm{Me}$ in the equilibrium phases have been discussed earlier elsewhere [40, 41].

Due to the relatively high solubility of silver in iron silicate slags, even at metallic iron saturation, its distribution coefficient is much less than that of gold, see Figs. 11 and 12. The experimental scatter in the distribution coefficient values is relatively large. It suggests evident post quenching mass transfer, due to insufficient quenching rate of the sample and as consequence of the large mass of the sampleampoule arrangement. The distribution coefficient values obtained for silver, however, are clearly higher than obtained in earlier open crucible arrangements, e.g., Yazawa [40], Avarmaa et al. [27] and Sukhomlinov et al. [42]. This fact is also supported by the present high concentrations of silver measured in the slag and alloy compared with the fully open experimental assemblies where Ag volatilization was significant [27].

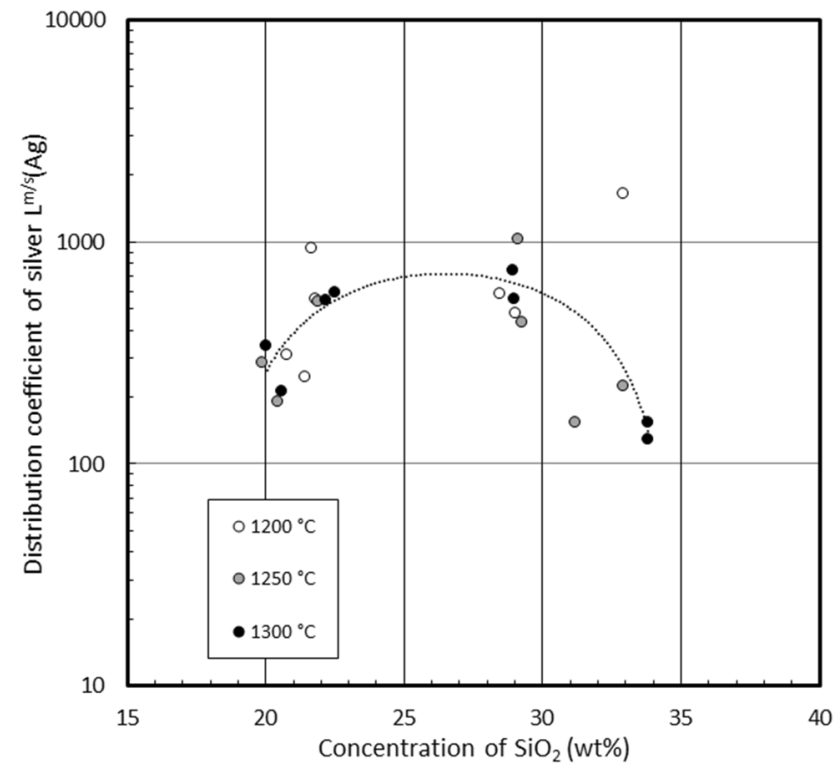

Fig. 11 Distribution coefficients of silver between copper and slag at iron saturations

A small temperature dependence is also found in the present results for the distribution coefficients of silver and gold so that low temperatures favor trace element deportment in the metal alloy, except at low silica concentrations.

The distribution coefficients of gallium and indium are shown in Figs. 13 and 14. A clear dependence of the Fe: $\mathrm{SiO}_{2}$ ratio can be observed in the case of gallium, but it is very small for indium. Also the temperature dependencies follow a similar pattern. A high processing temperature seems to favor the deportment of gallium in copper alloy, but in the

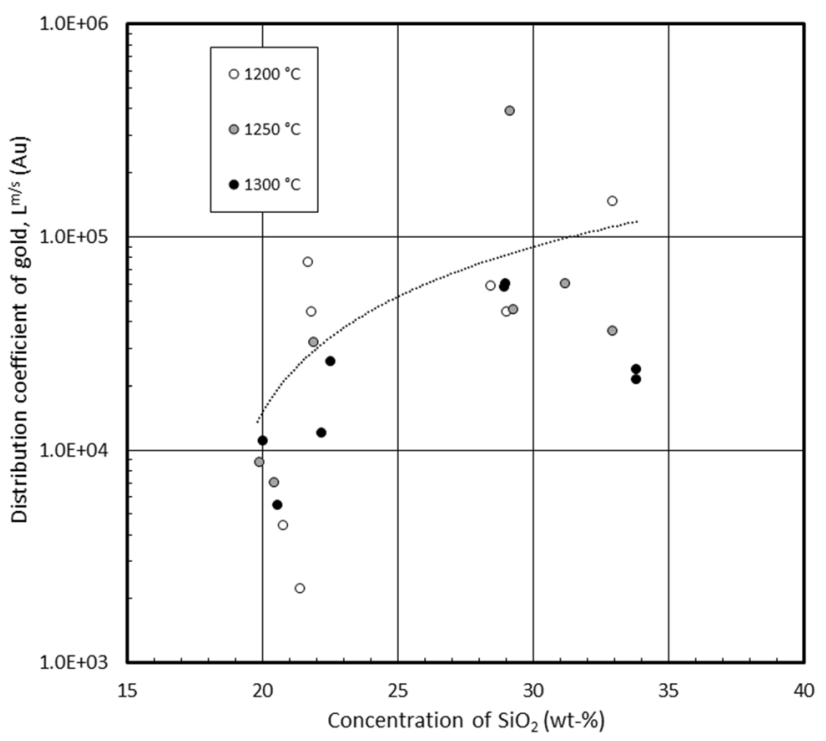

Fig. 12 Distribution coefficients of gold between copper and slag at iron saturations 


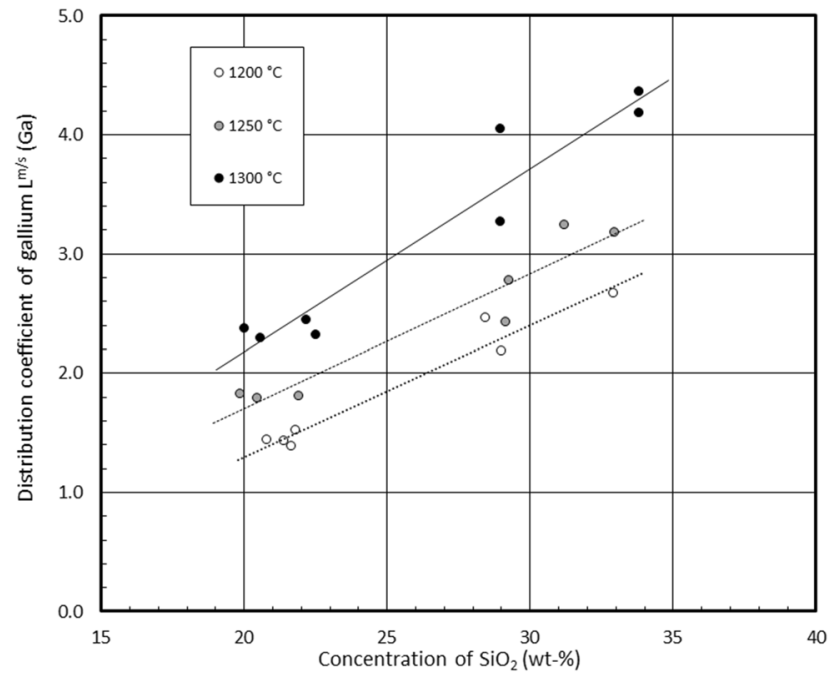

Fig. 13 Distribution coefficients of gallium between copper and slag at iron saturations; EPMA data

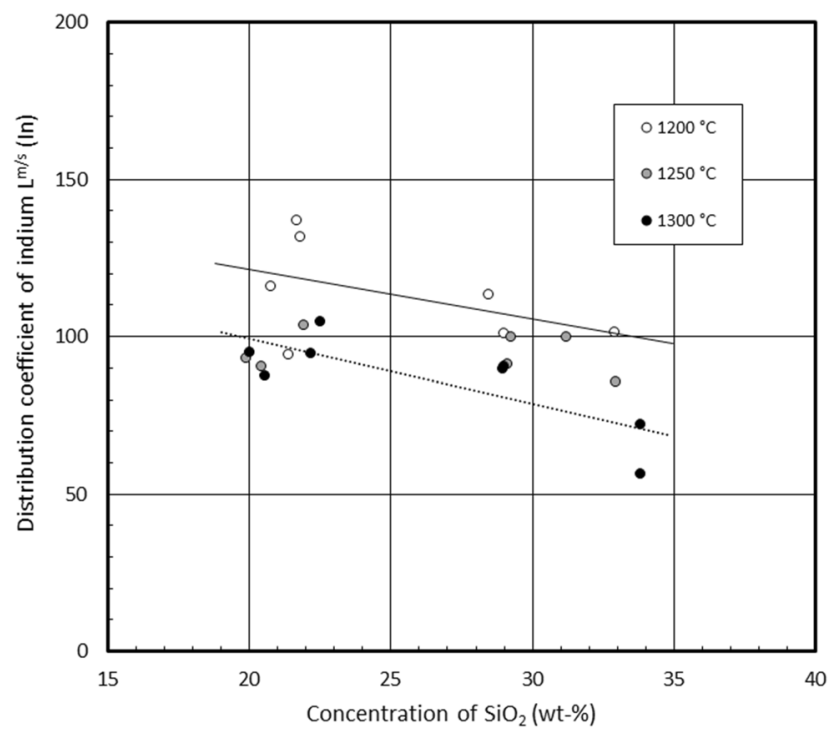

Fig. 14 Distribution coefficients of indium between copper and slag at iron saturations

case of indium, temperature has only a small impact on the distribution equilibria. According to the solubility measurements by Ko et al. [38], silica increases the solubility in ironfree silicate slags which is an opposite trend to that found in the present study.

The copper-slag distribution coefficients for germanium and antimony are presented in Figs. 15 and 16. Both elements distribute predominantly in the copper alloy with very high distribution coefficients of a few hundreds and thousands, respectively. Also the influence of the slag $\mathrm{Fe}: \mathrm{SiO}_{2}$ ratio is significant in both cases. The obtained distribution coefficients for antimony are on an order of magnitude larger than that

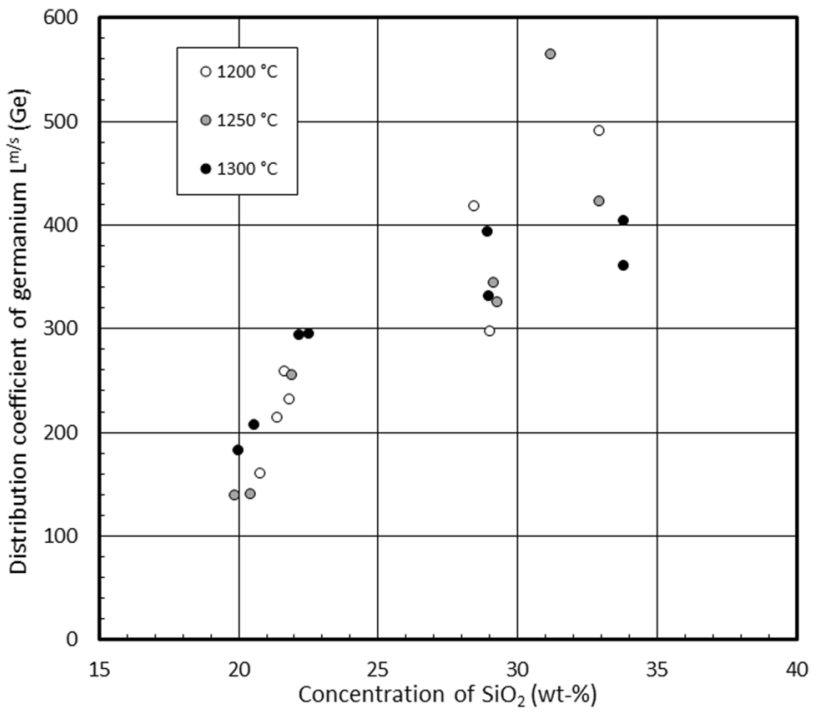

Fig. 15 Distribution coefficients of germanium between copper and slag at iron saturations at $1473-1573 \mathrm{~K}\left(1200-1300{ }^{\circ} \mathrm{C}\right)$

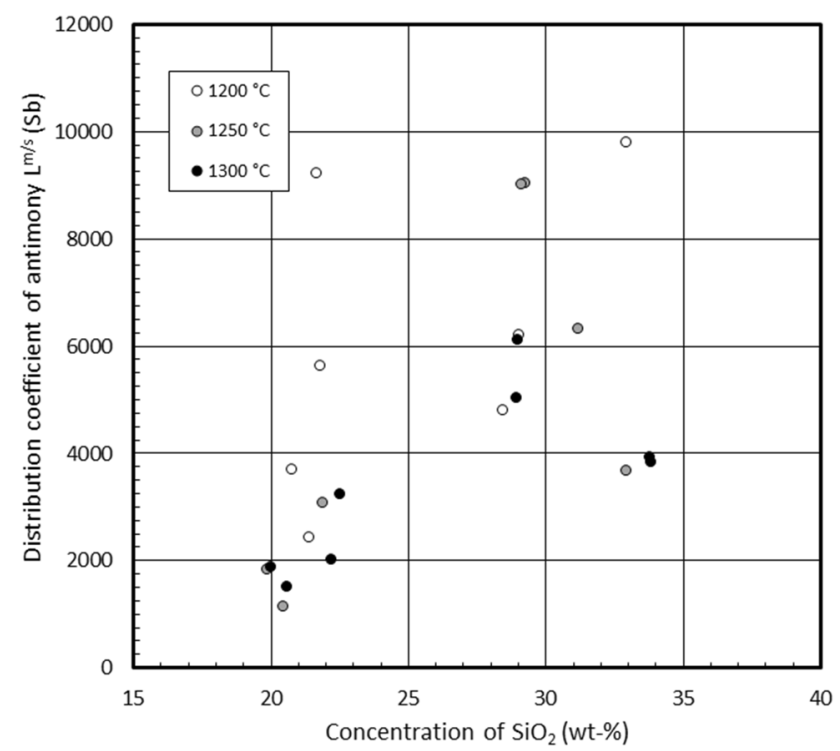

Fig. 16 Distribution coefficient of antimony between copper and slag at iron saturations at $1473-1573 \mathrm{~K}\left(1200-1300{ }^{\circ} \mathrm{C}\right)$

reported by Goto et al. [39] at $1200-1250{ }^{\circ} \mathrm{C}$ and silica saturation, but well in line with a recent publication from this group [43]. Shuva et al. [44] compared the previous germanium distribution experiments in copper and lead smelting slags but misinterpreted the data by Yan and Swinbourne [45]. The present observations indicate a stronger deportment to the metal alloy compared to the earlier data at $\mathrm{MgO}$ saturation and 5-19 wt \% CaO. The evident reasons for this are the slow cooling post equilibration and concentration gradients in a system where most germanium was lost during the equilibration. The 
present observations are, however, in good agreement with geochemical data [46].

A part of the $\mathrm{FeO}-\mathrm{Fe}_{2} \mathrm{O}_{3}-\mathrm{SiO}_{2}$ isothermal section at $1573 \mathrm{~K}\left(1300{ }^{\circ} \mathrm{C}\right)$ in ferric oxide lean systems is shown in Fig. 17, where the corners of the triangle have been defined as $90 \mathrm{wt} \% \mathrm{Fe}+10 \mathrm{wt} \% \mathrm{SiO}_{2}, 40 \mathrm{wt} \% \mathrm{FeO}+60 \mathrm{wt} \% \mathrm{SiO}_{2}$, and 40 wt $\% \mathrm{FeO}+50 \mathrm{wt} \% \mathrm{Fe}_{2} \mathrm{O}_{3}+10 \mathrm{wt} \% \mathrm{SiO}_{2}$. In addition to phase boundaries, based on Mtox database of MTDATA software [47], calculated isoactivity contours of $\mathrm{FeO}$ and $\mathrm{SiO}_{2}$ have been superimposed on the graph.

As Fig. 17 indicates, the properties of the slag 'matrix' change significantly when its composition is moved from halite $(\mathrm{FeO})$ saturation of low silica toward the silica-saturated assays, particularly at iron saturation where its silica activity is increased from about $\mathrm{a}\left(\mathrm{SiO}_{2}\right)=0.15$ to 1 (with solid tridymite as standard state). At the same time, the activity of ferrous oxide decreases from about $\mathrm{a}(\mathrm{FeO})=0.8$ to 0.35 (referred to pure, liquid $\mathrm{FeO}$ ). In Fig. 17, the isoactivity contours of ferrous oxide (from 0.3 to 0.8 ) are reproduced with labels of two decimals and those of silica (from 0.150 to 0.950 ) with three decimals.

Based on those fundamental features, it is easy to understand the obtained trends of the trace element concentrations in the iron silicate slags at iron saturation. Due to the experimental setup, the reduction process of the oxide of metal Me and solubility is controlled by the equilibrium:

$\mathrm{Fe}(\mathrm{s})+\left(\mathrm{MeO}_{x}\right)=[\mathrm{Me}]_{\mathrm{Cu}}+\left(\mathrm{FeO}_{x}\right)$
On the raw material side, the only variable is the activity of the metal oxide, and thus its final concentration in the slag, whereas on the product side, low activity coefficient of $\mathrm{Me}$ in copper and low activity of $\mathrm{FeO}_{x}$ in the slag promote the depletion of the slag from the trace element. It allows for generation of a stable slag without excessive leaching of its harmful metal content $[48,49]$. An excessive addition of silica must be avoided, due to, e.g., the increasing viscosity of the slag [50] and the decreasing reaction rates.

\section{Conclusions}

Molten silicate solutions are nonideal solution phases, due to the strong polymerization or associates formed by $\mathrm{SiO}_{2}$ with basic oxides, such as $\mathrm{CaO}$ and $\mathrm{MgO}$, but also with weaker silicate formers, e.g., $\mathrm{CoO}, \mathrm{FeO}$, and $\mathrm{NiO}$ [51]. This implies that no free basic oxides, or their cations, are present in the silicate slag compositions rich in $\mathrm{SiO}_{2}$, and thus, the thermodynamic activity coefficients of the basic components and, in particular, strong silicate formers under these conditions are very much below unity.

The residual concentrations of precious metals, germanium, and antimony as well as indium obtained at iron saturation, i.e., in highly reducing conditions, indicate that they can be recovered from the slag almost completely, but gallium concentrations in the slag at iron saturation were high. Its removal from iron residues, such as jarosite from zinc
Fig. 17 Calculated isoactivity contours of silica and ferrous oxide in the system $\mathrm{FeO}-\mathrm{Fe}_{2} \mathrm{O}_{3}$ $\mathrm{SiO}_{2}$ at $1573 \mathrm{~K}\left(1300{ }^{\circ} \mathrm{C}\right)$ and in $1 \mathrm{~atm}$ total pressure (dotted lines) $\mathrm{SiO}_{2}$ and (continuous line) $\mathrm{FeO}$ (standard states: $\mathrm{SiO}_{2}$ (s, tridymite) and $\mathrm{FeO}(\mathrm{l})$; Mtox database [47])

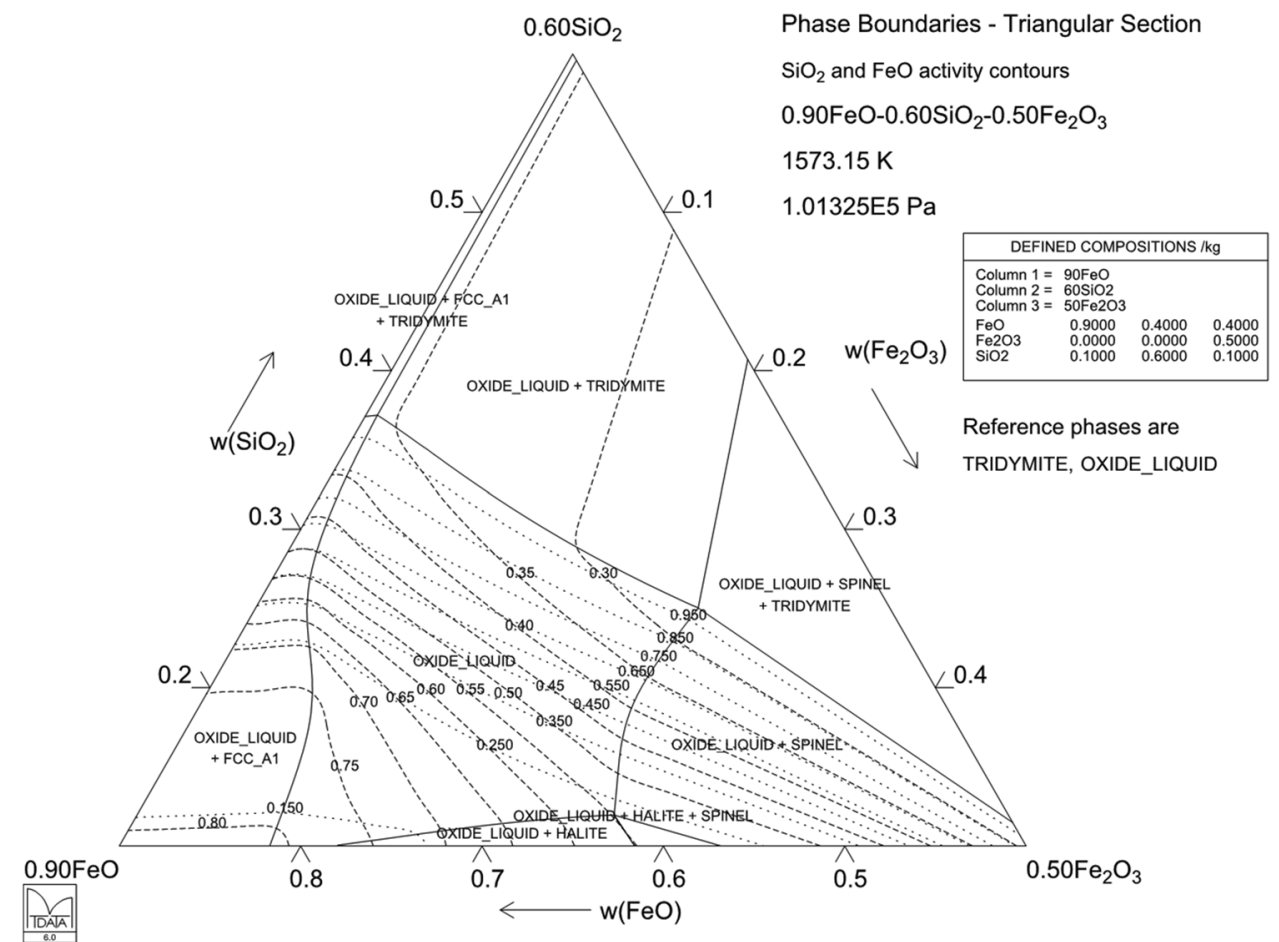


smelting, with a reasonable yield is thus difficult without volatilization during processing.

The results indicate the key importance of the $\mathrm{Fe}: \mathrm{SiO}_{2}$ ratio of the iron silicate slag to the residual concentration of a trace element in the endpoint of slag cleaning by chemical reduction. With strong silicate formers as trace elements, more basic fluxing components are needed to release the trace element from the slag. A typical example for this is lead smelting where lime is used for increasing lead recoveries from the slag. The solubilities of the minor components grow significantly when the slag assay is more basic than the orthosilicate composition (e.g., $\mathrm{Fe}_{2} \mathrm{SiO}_{4}$ ), all 'bridging oxygen' has been consumed in the silicate network by the basic oxide for the formation of $\mathrm{SiO}_{4}{ }^{4-}$ tetrahedra, and 'free' iron oxides are present in the molten silicate structure [52].

The industrial reduction technologies used for processing of iron residues and extracting reducible metal oxides and their metal values require a proper fluxing. Based on the present observations on the iron-saturated iron silicate slags, the target should be to maintain the slag compositions higher than about $28 \mathrm{wt} \% \mathrm{SiO}_{2}$ by fluxing with silica. Also the residual concentration of lead from the iron residue is low in the silicate slag under those conditions [23].

It is obvious that several trace metals tend to vaporize during the smelting process [53] and are transferred to the off-gas stream where they form flue dust at low temperatures, in the heat-recovery boiler and the subsequent electrostatic precipitator.

Acknowledgements Open access funding provided by Aalto University. The authors are indebted to the Business Finland (former Tekes) and Boliden Kokkola for financial support within the framework of the program CM Eco (Grant \# 7405/we31/2016). The EPMA analyses were carried out by Mr Lassi Pakkanen of GTK (Geological Survey of Finland, Espoo).

\section{Compliance with Ethical Standards}

Conflict of interest The authors declare that they have no conflicts of interest.

Open Access This article is distributed under the terms of the Creative Commons Attribution 4.0 International License (http://creativeco mmons.org/licenses/by/4.0/), which permits unrestricted use, distribution, and reproduction in any medium, provided you give appropriate credit to the original author(s) and the source, provide a link to the Creative Commons license, and indicate if changes were made.

\section{References}

1. Shen H, Forssberg E (2003) An overview of recovery of metals from slags. Waste Manag 23(10):933-949

2. Subramanian K, Themelis N (1972) Copper recovery by flotation. JOM 24(4):33-38
3. Demetrio S, Ahumada J, Durán M, Mast E, Rojas U, Sanhueza J, Reyes P, Morales E (2000) Slag cleaning: the Chilean copper smelter experience. JOM 52(8):20-25

4. Warner AE, Diaz C, Dalvi A, Mackey P, Tarasov A, Jones R (2007) JOM world nonferrous smelter survey Part IV: nickel: sulfide. JOM 59(4):58-72

5. Willis GM (1980) The physical chemistry of lead smelting. In: Cigan JM, Mackey P, O'Keefe TJ (eds) Proceedings of leadzinc-tin '80. The Metallurgical Society of AIME, Warrendale, pp $457-476$

6. Floyd J (1980) The physical chemistry of tin smelting. In: Cigan JM, Mackey P, O'Keefe TJ (eds) Proceedings of leadzinc-tin ' 80 . The Metallurgical Society of AIME, Warrendale, pp 508-531

7. Navarro A, Cardellach E, Mendoza J, Corbella $\mathrm{M}$, Domènech L (2008) Metal mobilization from base-metal smelting slag dumps in Sierra Almagrera (Almeriá, Spain). Appl Geochem 23(4):895-913

8. Choi CY (1996) Evolution of iron separation processes in zinc smelting at Korea Zinc. In: Dutrizac J, Harris G (eds) Iron control and disposal. CIM, Montreal, pp 199-210

9. Esna-Ashari M (1966) Thermische Behandlung von zinkhaltigen Jarosit-Rückständen im CONTOP-Schmeltzzyklon. Erzmetall 49(5):314-321

10. Peacey J, Hancock P (1996) Review of pyrometallurgical processes for treating iron residues from electrolytic zinc plants. In: Dutrizac J, Harris G (eds) Iron control and disposal. CIM, Montreal, pp 17-35

11. Choi CY, Lee YH (1999) Treatment of zinc residues by Ausmelt Technology at Onsan zinc refinery. In: Gaballah I, Hager J, Solozbal R (eds) Proceedings of REWAS '99. TMS, Warrendale, pp $1613-1622$

12. Kim B, Jeong S, Lee J, Shin D, Moon N (2012) Behaviors of lead and zinc in top submerged lance (TSL) plant at Sukpo zinc refinery. Mater Trans 53(5):985-990

13. Creedy S, Glinin A, Matusewicz R, Hughes S, Reuter M (2013) Outotec Ausmelt technology for treating zinc residues. Erzmetall 66(4):230-235

14. Wang X, Xie K, Ma W, Yang M, Zeng P, Cao Y (2013) Recovery of zinc and other valuable metals from zinc leaching residue by top blowing fuming method. Miner Process Extr Metall 122(3): $174-178$

15. Kim G, Sohn $\mathrm{H}$ (1998) Effects of $\mathrm{CaO}, \mathrm{Al}_{2} \mathrm{O}_{3}$, and $\mathrm{MgO}$ additions on the copper solubility, ferric/ferrous ratio, and minorelement behavior of iron-silicate slags. Metall Mater Trans B 29B(3):583-590

16. Zhai X, Li N, Zhang X, Fu Y, Jiang L (2011) Recovery of cobalt from converter slag of chambishi copper smelter using reduction smelting process. Trans Nonferrous Met Soc China 21(10):2117-2121

17. Banda W, Morgan N, Eksteen J (2002) The role of slag modifiers on the selective recovery of cobalt and copper from waste smelter slag. Miner Eng 15(11):899-907

18. Surapunt S, Takeda Y, Itagaki K (1995) Dissolution of zinc in $\mathrm{CaO}-\mathrm{SiO}_{2}-\mathrm{FeO}_{\mathrm{x}}$ slag coexisting with liquid $\mathrm{Cu}-\mathrm{Zn}-\mathrm{Fe}$ (iron-saturation) alloy. Shigen-to-Sozai 111(8):553-558

19. Zajaczkowski A, Botor J, Czernecki J (2006) Thermodynamics of copper and lead in alumina saturated flash smelting slag. Can Metall Q 43(3):417-430

20. Henao H, Hino M, Itagaki K (2001) Distribution of $\mathrm{Ni}, \mathrm{Cr}, \mathrm{Mn}$, $\mathrm{Co}$ and $\mathrm{Cu}$ between $\mathrm{Fe}-\mathrm{Ni}$ alloy and $\mathrm{FeO}_{\mathrm{x}}-\mathrm{MgO}-\mathrm{SiO}_{2}$ base slags. Mater Trans 42(9):1959-1966

21. Li G, Tsukihashi F (2001) Distribution equilibria of Fe Co, and $\mathrm{Ni}$ between $\mathrm{MgO}$-saturated $\mathrm{FeOx}-\mathrm{MgO}-\mathrm{SiO}_{2}$ slag and $\mathrm{Ni}$ alloy. ISIJ Int 41(11):1303-1308 
22. Kitamura S, Kuriyama H, Maruoka N, Yamaguchi K, Hasaegawa A (2008) Distribution of cobalt between $\mathrm{MgO}$-saturated $\mathrm{FeO}_{\mathrm{x}}-\mathrm{MgO}-\mathrm{CaO}-\mathrm{SiO}_{2}$ slag and $\mathrm{Fe}-\mathrm{Cu}-\mathrm{Co}$ molten alloy. Mater Trans 49(11):2636-2641

23. Hellstén N, Taskinen P, Johto H, Jokilaakso A (2018) Trace metal distributions in nickel slag cleaning. In: Davis B, Moats M, Wang $\mathrm{S}$ (eds) Extraction 2018: proceedings of the first global conference on extractive metallurgy. TMS, Pittsburgh, pp 379-389

24. Pouchou JL, Pichoir F (1986) Basic expression of "PAP" computation for quantitative EPMA. In: Brown JD, Packwood RH (eds) Proceedings of the 11th international congress on X-ray optics and microanalysis (ICXOM). University of Western Ontario, Ontario, pp 249-256

25. Jochum KP, Weis U, Stoll B, Kuzmin D, Yang Q, Raczek I, Jacob DE, Stracke A, Birbaum K, Frick DA, Günther D, Enzweiler J (2011) Determination of reference values for NIST SRM 610617 glasses following ISO guidelines. Geostand Geoanal Res 35(4):397-429

26. Van Achterberg E, Ryan C, Jackson S, Griffin W (2001) Data reduction software for LA-ICP-MS. Laser ablation ICP-MS in the earth science. Mineralogical Association of Canada, St John, pp 239-243

27. Avarmaa K, O'Brien H, Taskinen P (2016) Equilibria of gold and silver between molten copper and $\mathrm{FeO}_{\mathrm{x}}-\mathrm{SiO}_{2}-\mathrm{Al}_{2} \mathrm{O}_{3}$ slag in WEEE smelting at $1300{ }^{\circ} \mathrm{C}$. In: Reddy R, Chaubal P, Pistorius PC, Pal $\mathrm{U}$ (eds) Advances in molten slags, fluxes, and salts: proceedings of the 10th international conference on molten slags, fluxes, and salts. TMS, Pittsburgh, pp 193-202

28. Oelsen W, Schürmann E, Florin C (1961) Zur Kalorimetrie und Thermodynamik der Eisen-Kupfer-Legierungen. Arch Eisenhüttenwes 32(10):719-728

29. Chen Q, Jin Z (1995) The Fe-Cu system: a thermodynamic evaluation. Metall Mater Trans A 26A(2):417-426

30. Turchanin M, Agraval P, Nikolaenko I (2003) Thermodynamics of alloys and phase equilibria in the copper-iron system. J Phase Equilib 24(4):307-319

31. Shubhank K, Kang Y (2014) Critical evaluation and thermodynamic optimization of $\mathrm{Fe}-\mathrm{Cu}, \mathrm{Cu}-\mathrm{C}$, and $\mathrm{Fe}-\mathrm{C}$ binary systems and Fe-Cu-C ternary system. CALPHAD 45:127-137

32. Arita M, Tanaka M, Goto K, Someno M (1981) Activity and diffusivity measurements of copper in $\gamma$ and $\delta \mathrm{Fe}$ by equilibration between solid Fe and liquid Ag. Metall Trans A 12A(3):497-504

33. Capobianco C, Drake M, de Aro J (1999) Siderophile geochemistry of $\mathrm{Ga}, \mathrm{Ge}$ and $\mathrm{Si}$ : cationic oxidation states in silicate melts and the effect of composition in iron-nickel alloys. Geochim Cosmochim Acta 43(17):2667-2672

34. Hughes S (2000) Applying Ausmelt technology to recover $\mathrm{Cu}, \mathrm{Ni}$, and Co from slags. JOM 52(8):30-33

35. Wegscheider S, Steinlechner S, Leuchtenmüller M (2016) Innovative concept for the recovery of silver and indium by a combined treatment of jarosite and electric arc dust. JOM 69(2):388-394

36. Borisov A, Palme H (2000) Solubilities of noble metals in Fecontaining silicate melts as derived from experiments in Fe-free systems. Am Miner 85(11-12):1665-1673

37. Swinbourne DR, Yan S, Salim S (2005) The solubility of gold in metallurgical slags. Miner Process Extr Metall 114(1):23-29

38. Ko KY, Park JH, Hong SH (2011) Dissolution mechanism of indium in molten $\mathrm{CaO}-\mathrm{SiO} 2-\mathrm{Al} 2 \mathrm{O} 3$ slag. In: Kongoli F (ed) Fray international symposium, vol 1. Flogen, Mont-Royal, pp 287-298
39. Goto S, Ogawa O, Inoue Y, Ohara H (1979) On the equilibria between $\mathrm{Cu}-\mathrm{Sb}$ alloys and silica-saturated iron silicate slags. Shigen-to-Sozai 95(4):205-211

40. Yazawa A (1980) Distribution of various elements between copper, matte and slag. Erzmetall 33(7-8):377-382

41. Piskunen P, Avarmaa K, O'Brien H, Klemettinen L, Johto H, Taskinen P (2017) Precious metals distributions in direct nickel matte smelting with low-copper mattes. Metall Mater Trans B 49B(1):98-112

42. Sukhomlinov D, Taskinen P (2017) Distribution of Ni, Co, Ag, $\mathrm{Au}, \mathrm{Pt}$ and Pd between copper metal and silica saturated iron silicate slag. In: Proceedings of the EMC 2017, June 25-28, Leipzig, vol 3. GDMB, Clausthal-Zellerfeld, pp 1029-1038

43. Klemettinen L, Avarmaa K, O'Brien H, Taskinen P, Jokilaakso A (2019) Behavior of tin and antimony in secondary copper smelting process. Minerals 9(1):39

44. Shuva MAH, Rhamdhani MA, Brooks GA, Masood S, Reuter MA (2016) Thermodynamics behavior of germanium during equilibrium reactions between $\mathrm{FeO}_{\mathrm{x}}-\mathrm{CaO}-\mathrm{SiO}_{2}-\mathrm{MgO}$ slag and molten copper. Metall Mater Trans B 47B(5):2889-2903

45. Yan S, Swinbourne DR (2003) Distributions of germanium under lead smelting conditions. Miner Process Extr Metall 112(2):75-80

46. Holzapfel C, Courtial P, Dingwell DB, Chakraborty S, Palme H (2001) Experimental determination of partial molar volumes of $\mathrm{Ga}_{2} \mathrm{O}_{3}$ and $\mathrm{GeO}_{2}$ in silicate melts: implications for the pressure dependence of metal-silicate partition coefficients. Chem Geol 174(1):33-49

47. Gisby J, Taskinen P, Pihlasalo J, Li Z, Tyrer M, Pearce J, Avarmaa K, Björklund P, Davies H, Korpi M, Martin S, Pesonen L, Robinson J (2017) MTDATA and the prediction of phase equilibria in oxide systems: 30 years of industrial collaboration. Metall Mater Trans B 48B(1):91-98

48. Pisciella P, Crisucci S, Karamanov A, Pelino M (2001) Chemical durability of glasses obtained by vitrification of industrial wastes. Waste Manag 21(1):1-9

49. Mombelli D, Mapelli C, Cecca C, Barella S, Gruttadauria A, Ragona M, Pisu M, Viola A (2018) Characterization of cast iron and slag produced by jarosite sludges reduction via arc transferred plasma (ATP) reactor. J Environ Chem Eng 6(1):773-783

50. Mills K (2011) The estimation of slag properties. In: Jones RT, Hoed P (eds) Southern African pyrometallurgy 2011. The SA Institution of Mining and Metallurgy, Johannesburg, pp S1-S52

51. Gaskell D (1981) J Tien, J Elliott (eds) The thermodynamic properties and structures of slags. Metallurgical treatises. The Metallurgical Society of AIME, Warrendale, pp 59-77

52. Masson C (1984) The thermodynamic properties and structures of slags. In: Fine H, Gaskell D (eds) Proceedings of the 2nd international symposium metallurgical slags and fluxes. TMS, Warrendale, pp 3-44

53. Avarmaa K, Yliaho S, Taskinen P (2018) Recoveries of rare elements $\mathrm{Ga}, \mathrm{Ge}$, In and $\mathrm{Sn}$ from waste electric and electronic equipment through secondary copper smelting. Waste Manage 71(1):400-410

Publisher's Note Springer Nature remains neutral with regard to jurisdictional claims in published maps and institutional affiliations. 